\title{
Who was Pierre Marie?
}

\author{
Quem foi Pierre Marie? \\ Péricles MARANHÃO-FILHO' ${ }^{1}$ Maurice VINCENT²
}

\begin{abstract}
In this manuscript we pay a tribute to Pierre Marie (1853-1940), highlighting his great contribution to medicine and neurology describing several diseases and syndromes. We mainly emphasize aspects of his personal life and personality traits. Considered one of the three greatest neurologists of the late nineteenth and early twentieth centuries, his brilliant career began at La Salpêtrière, followed by the development of a neurological school at Hospice Bicêtre. Pierre Marie had numerous disciples around the world, including Brazil, and published on various neurological and endocrinological themes. Back to La Salpêtrière, he concluded his professional life as a Neurology leader. However, after retirement, his demise was sad and lonely
\end{abstract}

Keywords: Neurology; History; Pierre Marie.

\section{RESUMO}

Neste manuscrito, prestamos homenagem a Pierre Marie (1853-1940), destacando sua grande contribuição para a medicina e a neurologia, descrevendo várias doenças e síndromes. Enfatizamos principalmente aspectos de sua vida pessoal e traços de personalidade. Considerado um dos três maiores neurologistas do final do século XIXe início do século XX, sua brilhante carreira começou em La Salpêtrière, seguida pelo desenvolvimento de uma escola de neurologia no Hospice Bicêtre. Pierre Marie teve numerosos discípulos em todo o mundo, incluindo o Brasil, e publicou sobre vários temas neurológicos e endocrinológicos. De volta a La Salpêtrière, ele concluiu sua vida profissional como líder da Neurologia. Porém, após aposentadoria, seu ocaso foi triste e solitário

Palavras-chave: Neurologia; História; Pierre Marie.

Georges-Eugène Haussmann, nominated prefect de la Seine on June 23, 1853, altered dramatically and definitely the Paris urban plan. Pierre Marie, a remarkable physician born in the ville des lumières two months and 18 days later, would open new avenues on our understanding of neurology.

\section{THE MAN}

Pierre Marie, one of the greatest French neurologists of the $19^{\text {th }}$ - early $20^{\text {th }}$ centuries, together with Duchenne and Charcot $^{1,2}$, was unique for his qualities as a pathologist, neurologist, researcher, writer, editor, and outstanding teacher. He defended his ideas passionately, always committed to integrity, searching obsessively for the truth.

As the only child of a wealthy family, Marie received excellent classical education, becoming fluent in Latin and Greek. He entered the Paris School of Medicine after fulfilling his father's wish - a law degree ${ }^{3,4,5}$. His strong and authoritarian traits contrasted with his average height. The square-cut gray hair and beard could give this actually pleasant and affable physician a false snobbish look (Figure 1); however, he had a deep, bright, and insightful mind ${ }^{1}$. He considered coffee

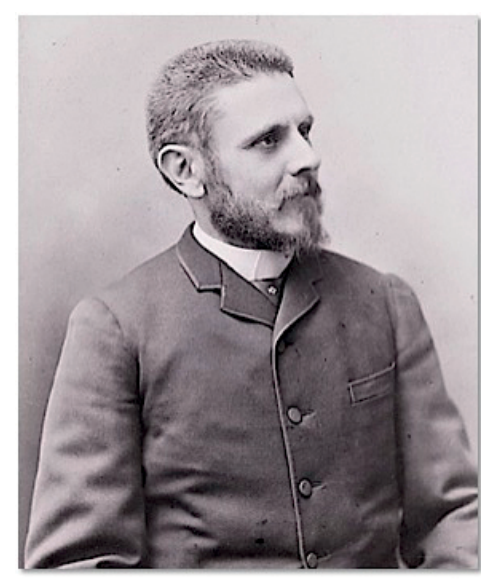

Figure 1. Doctor Pierre Marie, 1889. Extracted from: https:// upload.wikimedia.org/wikipedia/commons/8/84/Docteur_ Pierre_Marie.jpg [accessed in June 18, 2020].

\footnotetext{
'Universidade Federal do Rio de Janeiro, Rio de Janeiro RJ, Brazil.

${ }^{2}$ Eli Lilly and Company, Neuroscience Research, Indianapolis, USA.

Péricles MARANHÃO-FILHO (D) https://orcid.org/0000-0003-2030-547X; Maurice VINCENT (iD https://orcid.org/0000-0001-5855-6069

Correspondence: Péricles Maranhão-Filho; E-mail:pmaranhaofilho@gmail.com
}

Conflict of interest: Maurice Vincent is a stock-holding employee at Eli Lilly and Company; Péricles Maranhão-Filho states that there is no conflict of interest to declare.

Received on February 07, 2020; Received in its final form on February 07, 2020; Accepted on April 11, 2020.

\section{(cc) BY}


unpalatable, sipped small doses of plum liquor with relish, and always rolled his own cigarettes. Marie learned about religion and developed a taste for arts, becoming a great collector of sculptures, tapestries, furniture, and paintings. He enjoyed golfing, fencing, and excelled in hunting.

After graduating in 1883, he became Charcot's chef de clinique until 1885. Charcot was impressed by Marie's unique gifts of observation and discernment, besides his incredible accuracy in diagnosing obscure diseases. This brilliant clinician would sometimes stop his chauffeur just to recommend some treatment to a passerby ${ }^{4}$.

The loathing Marie felt for Jules Déjerine resulted in a dramatic episode ${ }^{3}$. In 1892, enraged by the harsh and rude words published against him by Marie, Déjerine sent messengers to Marie's house asking him to either retract his statements or set a time and place for a duel. Marie responded with a letter denying any attack to Déjerine's scientific integrity, so the duel never occurred beyond their dispute on aphasia localization in the brain. Notwithstanding, shortly after Marie took over the Chair of nervous system diseases at La Salpêtrière following Déjerine’s death (1917), he advised Déjerine’s wife - Augusta Déjerine Klumpke - that she had 14 days to leave La Salpêtrière with all Déjerine's staff and students ${ }^{3}$.

The work-addicted Pierre Marie and Édouard Brissaud founded the Revue Neurologique (1893) and the Société de Neurologie de Paris (1899) ${ }^{6}$. Most of his contributions occurred between his appointment to the Hospice de Bicêtre in 1897 (Figure 2) and 1907, when he accepted the position of Chair of Anatomical Pathology, school of Medicine, revolutionizing the hitherto teaching methods ${ }^{1}$. The worldwide renowned Neurology clinic Marie established at the Hospice attracted physicians from France and abroad, among whom was the young Brazilian doctor Aloysio de Castro, who wrote: "It was 1906. Eight o'clock in the morning, 211 Boulevard Saint Germain, and there I was in a carriage on my way to the old Hospice de Bicêtre, next to Pierre Marie. Arriving at the ward, where his senior assistants and foreign doctors were already waiting, he wasted no time, taking his coat and heading to

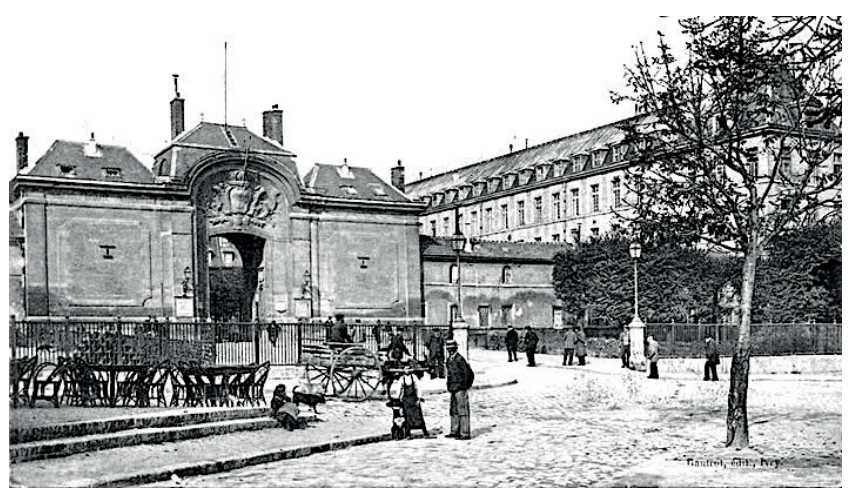

Figure 2. Kremlin-Bicêtre l'Hospice. Paris, 1906. Extracted from: http://www.leplaisirdesdieux.fr/LePlaisirDesDieux/ NosAncetresLesInternes/Hopitaux/bicetre/bicetre1.jpg [accessed in June 18, 2020] the nearest laboratory. Putting on his glasses, with a brain in his hand, he simply mentioned: "I was a Broca's intern, I was Charcot's assistant, but I firmly deny (...) the existence of an aphasia center at the foot of the third left frontal circumference..." . Marie had published extensively on aphasias, rejecting Broca's and Wernicke's views on language localization.

It is worth mentioning that back in Brazil, Aloysio de Castro established the first outpatient clinic-school in the country ${ }^{8}$ and published the book "Tractado de Semiótica Nervosa" in 1914", the first Brazilian book devoted to neurosemiotics, introducing the formal study of this subject in Brazil.

The neuropathologist Gustave Roussy, Marie's assistant, wrote: "Not only was he undeniably authoritarian to the point of intransigence and pride, [but] he liked to apply the ideas he developed, if only over the course of a discussion, to which he brought formidable skills" ${ }^{10}$. The American neurosurgeon Percival Bailey said: "I remember him as a dignified old gentleman. Only rarely did he enter the wards and never the laboratory. He was at his best in clinical consultation in which his discussion was short and pithy. His teaching was always simple and clear"s.

\section{THE FAMILY}

Marie preserved his private life, scorning public acclaim, honors, and titles. He married Blanche Savard (1888), an intellectually privileged, elegant, and charming woman from a wealthy Parisian family ${ }^{4}$. Marie, Savard, and their two children, Juliette and André, enjoyed a happy life, either in their mansion at 76 rue de Lille or in their two other properties, in Normandie and Le Pradet, French Riviera. Eventually, Juliette (10 years old) died from acute appendicitis; then Marie lost his devoted wife because of a thigh scratch turned into uncontrollable erysipelas; finally, his son, a 38-year-old doctor who was studying botulism at the Pasteur Institute, succumbed to this terrible infection ${ }^{4}$.

Marie retired (1925, 72 years old) and got involved with the education of his grandchildren, Françoise, Juliette, and Alain, to whom he loved teaching mythology ${ }^{1}$.

\section{THE END}

After retirement, Marie spent winters in Côte d'Azur where he wrote Travaux et memoires (1926-1928) - and summers in Normandie. ${ }^{5}$. The last part of his life was marked by loneliness in southern France, rarely meeting friends or former pupils, following politics and his assets in stock markets $^{4}$. Despite his preserved cognition, he developed progressive pain while walking, eventually needing a wheelchair.

In late 1939, Marie became anxious and stressed by the imminent war. A progressive abdominal discomfort brought 
him to Paris, where Thyerry Martel unsuccessfully operated him. Marie died in southern France (April 13, 1940) shortly before the Nazis invaded Paris. Just as his life - free of boasting or glory, despite his plentiful honors - , his passing was unremarkable. A small obituary was published in Nature (June 1940)11. Years later, the Revue Neurologique dedicated an issue to his immense contribution not only to Neurology but also to Medicine in general.

\section{References}

1. Sir Cohen H. Pierre Marie 1853-1940. Proc R Soc Med. 1953 Dec;46(12):1047-54

2. Almeida GM, Germiniani FMB, Teive HAG. The seminal role played by Pierre Marie in Neurology and Internal Medicine. Arq Neuropsiquiatr. 2015 Sep;73(10):887-9. http://dx.doi.org/10.1590/0004$282 \times 20150126$

3. Brais B. The third left frontal convolution plays no role in language: Pierre Marie and the Paris debate on aphasia (1906-1908). Neurology. 1992;42(3 Pt 1):690-5. https://doi.org/10.1212/wnl.42.3.690

4. Marie Granier MP. Life of doctor Pierre Marie: a great granddaughter's view. In: Robbins R, Melmed S, Editors. Proceedings of the Acromegaly Centennial Symposium. New York and London: Plenum Press, 1986. p.1-7.

5. Pearce JMS. A note on Pierre Marie (1853-1940). J Neurol Neurosurg Psychiatry. 2004 Nov;75(11):1583. https://doi.org/10.1136/ jnnp.2003.024729
6. Broussolle E, Poirier J, Clarac F, Barbara J-G. Figures and institutions of the neurological sciences in Paris from 1800 to 1950. Part III: Neurology. Rev Neurol (Paris). 2012 Apr;168(4):301-20. https://doi. org/10.1016/j.neurol.2011.10.006

7. Pontes JPL. Aloysio de Castro. Folha Méd. 1981 Set; 83(3):271-7.

8. Maranhão-Filho PA. Aloysio de Castro, o Precursor da Neurossemiologia no Brasil. Revista Brasileira de Neurologia. 2014;50(3):66-69 (In Portuguese).

9. Castro A. Tractado de Semiotica Nervosa. Rio de Janeiro: F. Briquiet \& Cia., 1914.

10. Walusinski O.Jules and Augusta Déjerine, Pierre Marie, Joseph Babinski, Georges Guillain and their students during World War I. Rev Neurol (Paris). 2017 Mar;173(3):114-24. https://doi.org/10.1016/j. neurol.2017.02.001

11. Rolleston JD. Prof. Pierre Marie Obituary Nature. 1940 Jun:145:925. https://doi.org/10.1038/145925a0 